\title{
SKIN HUNGER
}

\author{
A sense of loss.
}

\section{BY BO BALDER}

K irsten knocked. The carved ebony knocker landed soundlessly on velvet. The door swung open and she entered the dark hallway. The door closed, not with a sound but with an intensification of the air inside, making it dryer, darker and more silent.

She waited until her eyes had got used to the darkness. Sometimes she felt anticipation, sometimes dread. Often she felt nothing much. She appreciated the efforts of her hosts, but gratitude no longer had the power to mitigate the realization that she'd never get out of here. As the only survivor of the crash, what she missed most was other humans.

A light glowed up at the end of the hallway. The layout of the facility changed with every visit. Surprise and curiosity were emotions as well, and again, they did their best.

Kirsten started walking, reluctant to let go of her anticipatory state. Her feet touched warm, non-resonant flooring that came close to being wood. Close enough for her soles, if not for her ears and sense of smell. Even though her mind was sinking into despair, her body could still react to small pleasures. She rolled her soles over the floor, savouring the moment, wishing she could store the sensation.

A seven-foot dragon burst from the ceiling and shrieked in her face.

Kirsten's heartbeat accelerated slightly. If only she could still experience the full range of emotions. Her mind knew this was a side effect of depression, but that didn't seem to change anything. The dragon flapped its kimono wings and stomped its booted feet. The bright reds and yellows of the dress, the gyrations and dips of the dance were gorgeous. As were the tinkling, winking headdress decorations, like seahorse antennae. Kirsten clapped politely. The unmoving mask turned in her direction, the figure took a bow and vanished.

Beauty and grace moved her only a little. Her hosts had tried ugliness and stenches and danger to stir her, and that had worked in the beginning. But everything palled eventually, so they had reverted to recreating familiarity. Although Noh hadn't been in her cultural vocabulary back on Earth.

Fuzzy blackness descended over her head. Kirsten fought, from real surprise, but her captors jostled her, rolled her over, carried

The aliens lowered Kirsten into a warm mud bath, which was a regular occurrence during the ritual. It was the one thing they got right, simply because she'd never had one back home. Submerged younglings massaged her sore body with their tentacles.

Something warm touched her shoulders. She leaned forward so they could massage her. Warm, slightly rough fingers dug into her tight shoulders in just the right places. How had they learned this? She imagined tentacled beings practising on each other's non-existent shoulder muscles, or on Kirsten dolls. She smiled. That was a good feeling, even if her smile muscles tired quickly.

Then a sensation ghosted over her back, as if the masseur's hairy underarm accidentally touched her back. Her body flooded with adrenaline, the hair rose on her neck, her breath caught in her throat. The touch of another human being's skin. The thing she'd

her somewhere while she bounced on their bodies, was banged against obstacles and felt sick to her stomach. Surprise? Check. Discomfort? Check. Nausea? Bruising? Even unpleasant sensations were welcome.

She was squeezed out of her sack, the clothes ripped from her body, rolled around in scalding water and beaten with something like rubber hose. Only it wouldn't be rubber, or hose. Probably her hosts' tentacles. Just being aware of that possibility made it feel less real.

Gentle touches soothed her skin with water almost smelling like jasmine. So close. How did her nose even know it wasn't the real thing, after so long without it? Maybe she was hallucinating and that was why nothing felt quite real. It was as if the real Kirsten, the one with depth and warmth, was just behind a $\rightarrow$ NATURE.COM Follow Futures: - @Naturefutures If gonature.com/mtoodm curtain, tantalizingly within reach. She kept thinking that she'd find that person again, soon. Tomorrow. missed more than words.

"Who are you?" the real Kirsten said, sharply.

She must have startled the masseur, because she glimpsed a flash of an old cashmere sweater of hers it held in two tentacles. The illusion shattered.

She cried so hard it hurt. For that one moment she'd been back to her old self again, but it was worse than feeling everything through a veil. She was going to die alone. Without ever having touched another human being again.

She rose from the mud-bath, drying her tears. No more rituals. She never wanted to experience another moment of hope like that. It hurt too much.

Bo Balder is the first Dutch author to be published in Fantasy \& Science Fiction. Her short fiction has appeared in Crossed Genres, Futuristica Volume 1 and other venues. Her SF novel The Wan is published by Pink Narcissus Press. 